\title{
PROGRAMAÇÃO ORÇAMENTÁRIA NAS MENSAGENS PRESIDENCIAIS: A EDUCAÇÃO SUPERIOR NO PERÍODO DE 2004 A 2016
}

\author{
Celia Maria Haas (Unicid)* \\ http://orcid.org/0000-0002-8462-8350 \\ Luciana Formiga R. V. de Oliveira (ENAP)** \\ https://orcid.org/0000-0002-0922-6095
}

\section{RESUMO}

Este artigo analisa a relação entre a Mensagem Presidencial relativa ao Planos Plurianuais (PPA) e a programação dos recursos resultantes do investimento público federal em programas e ações destinados a este nível de ensino nas Mensagens Presidenciais, no que se refere ao financiamento da Educação Superior Brasileira, cotejando o prometido e o programado em seus anexos com o conteúdo referentes ao período de 2004 a 2016. Extraiu-se da mensagem presidencial o conteúdo relacionado à temática em estudo, e os dados relativos à programação orçamentária foram obtidos no portal do Ministério do Planejamento. A análise considerou os compromissos políticos, as prioridades e procedimentos expressos na Mensagem Presidencial e concretizados na definição orçamentária de cada Plano. Constatou-se que as Mensagens Presidenciais têm caráter de definições políticas que não são, necessariamente, concretizadas em previsões orçamentárias definidas no respectivo PPA. Identificou-se ainda que a relação entre o que foi prometido e o que foi programado vem evoluindo desde o primeiro PPA do período (2004 a 2007) até o último (2016 a 2019).

Palavras-chave: Plano Plurianual. Mensagem presidencial. Programação orçamentária. Educação superior.

\section{ABSTRACT}

\section{BUDGETARY PROGRAMMING IN PRESIDENTIAL MESSAGES: HIGHER EDUCATION IN THE PERIOD FROM 2004 TO 2016}

This article analyzes the relation between the Presidential Message on Pluriannual Plans (PPA) and the programming of the resources resulting from the federal public investment in programs and actions destined to this level of

Doutora em Educação (Supervisão e Currículo) pela Pontifícia Universidade Católica de São Paulo (PUC-SP). Professora titular no Programa de Mestrado em Educação da Universidade Cidade de São Paulo (Unicid). E-mail: celia.haas@unicid.edu.br

** Mestre em Educação pela Universidade Cidade de São Paulo (Unicid). Secretária Adjunta de Orçamento e Finanças do Ministério Público do Distrito Federal e Territórios. Professora do Centro Universitário do Distrito Federal e da Escola Nacional de Administração Pública (ENAP) nos cursos de Gestão do Orçamento Público e Gestão Orçamentária e Financeira. Orientadora pedagógica, conteudista e tutora da Escola Superior do Ministério Público da União (ESMPU). E-mail: professora.luciana. formiga@gmail.com 
education in the Presidential Messages, as far as the financing of Brazilian Higher Education is concerned, comparing the promised and programmed in its annexes with the content referring to the period from 2004 to 2016 . The contents related to the subject under study were extracted from the presidential message and data related to budget programming were obtained from the portal of the Ministry of Planning. The analysis considered the political commitments, priorities and procedures expressed in the Presidential Message and concretized in the budget definition of each Plan. It was found that the Presidential Messages have political definitions that are not necessarily fulfilled in the budget forecasts defined in the respective PPA. It was also identified that the relationship between what was promised and what was programmed has been evolving since the first PPA of the period (2004 to 2007) to the last one (2016 to 2019).

Keywords: Plurianual Plan. Presidential message. Budgetary programming. College education.

\section{RESUMEN \\ PROGRAMACIÓN PRESUPUESTARIA EN MENSAJES PRESIDENCIALES: EDUCACIÓN SUPERIOR EN EL PERÍODO DE 2004 A 2016}

Este artículo analiza la relación entre el Mensaje Presidencial sobre Planos Plurianuales (PPA) y la programación de los recursos resultantes de la inversión pública federal en programas y acciones destinados a este nivel de enseñanza en los Mensajes Presidenciales, en lo que se refiere al financiamiento de la Educación Superior Brasileña cotejando el prometido y el programado en sus anexos con el contenido referentes al período de 2004 a 2016. Se extrajo del mensaje presidencial el contenido relacionado a la temática en estudio y los datos relativos a la programación presupuestaria fueron obtenidos en el portal del Ministerio de Planificación. El análisis consideró los compromisos políticos, las prioridades y procedimientos expresados en el Mensaje Presidencial y concretado en la definición presupuestaria de cada Plan. Se constató que los Mensajes Presidenciales tienen carácter de definiciones políticas que no son necesariamente concretadas en previsiones presupuestarias definidas en el respectivo PPA. Se identificó además que la relación entre lo que se prometió y lo que se ha programado viene evolucionando desde el primer PPA del período (2004 a 2007) hasta el último (2016 a 2019).

Palabras clave: Plan Plurianual. Mensaje presidencial. Programación presupuestaria. Educación universitária.

\section{Introdução}

0 artigo trata do planejamento constante do Plano Plurianual (PPA) realizado no período de 2004 a 2016, a fim de conhecer as intenções orçamentárias, conteúdo da Mensagem Presidencial de cada plano e a sua respectiva programação, componente do Anexo relativo aos objetivos finalísticos do Estado, promovendo a relação entre o que foi dito e o que foi orçado. Para tanto, das Mensagens Presidenciais referentes aos planos de 2004-2007, 2008-2011, 2012-2015 e 2016-2019, selecionou-se o que se referia a educação superior, a partir da subfunção de governo 364, como é denominado o ensino superior. 
O objetivo da pesquisa foi cotejar o que foi expresso nas Mensagens Presidenciais dos Planos Plurianuais referentes ao período citado acerca da educação superior, aferindo sua correspondente programação no mesmo documento, permitindo verificar qual a relação entre o que foi afirmado como compromisso e o que foi programado.

Serviu de base de consulta a subfunção de governo de número 364, que trata da educação superior, conforme a classificação da despesa pública no Brasil, identificando-se as ações relativas a esse tipo de educação.

A pesquisa é de natureza quali-quantitativa (BAUER; GASKELL, 2002), uma vez que combina a compreensão do que se estabelece como prioridade na Mensagem Presidencial, em uma perspectiva qualitativa, com o cotejamento do que foi orçado na sua programação orçamentária, constante do Plano Plurianual, composto pelos dados quantitativos identificados. As mensagens presidenciais e os dados dos orçamentos nacionais foram obtidos no portal do Ministério do Planejamento.

Para a análise das mensagens considerou-se as indicações do que se pretendia realizar no período para a educação superior no Brasil, levantando-se o compromisso político, as prioridades, e os procedimentos.

0 compromisso político é aquele firmado entre o governante e a sociedade quando o primeiro afirma à população o que será feito em prol da segunda, e isso se concretiza pelo que é dito pelo governante na Mensagem Presidencial. Prioridades são aquelas que na mensagem presidencial devem ser organizadas em ações de governo, indicando a preferência do governante para que sejam conteúdo da programação orçamentária. Os procedimentos representam os meios para o alcance das diversas políticas públicas de governo que são relatadas na mensagem presidencial e representam a estratégia de atuação.

Os itens relativos à educação superior no Brasil são apresentados nesta seção, em conformidade com a ordem em que são men- cionados em cada Mensagem Presidencial do PPA.

Para cada uma dessas categorias foram identificados os valores orçamentários dispostos do maior para o menor, visando ressaltar o que foi considerado como prioridade pelo governo no momento da programação, verificandose a finalidade de cada ação, para finalizar analisando-se o conjunto das informações da mensagem presidencial, cotejando-se a relação entre a mensagem e o seu anexo.

As menções que resultaram na definição do compromisso político, prioridades e procedimentos da mensagem presidencial compõem a análise do apanhado da Mensagem Presidencial, sendo confeccionada uma planilha, ao final da seção, composta por esses itens e que serão a base, na seção seguinte, para a verificação da relação deste conteúdo com a programação orçamentária e financeira, constante dos anexos do PPA.

Cada PPA se compõe da Mensagem Presidencial, o texto da lei e quatro anexos, conforme estabelece o Art. $7^{\circ}$, da Lei no 13.249 , de 13 de janeiro de 2016:

Integram o PPA 2016-2019 os seguintes anexos:

I - Anexo I - Programas Temáticos;

II - Anexo II - Programas de Gestão, Manutenção e Serviços ao Estado; e

III - Anexo III - Empreendimentos Individualizados como Iniciativas - acima do Valor de Referência; e

IV - Anexo IV - Empreendimentos Individualizados como Iniciativas - Abaixo do Valor de Referência. (BRASIL, 2016).

O Plano Plurianual (PPA), sempre elaborado durante o primeiro ano de exercício do presidente eleito, é composto pelas metas e prioridades para o período de quatro exercícios financeiros. Assim, ao mesmo tempo em que planeja o novo plano, executa a programação feita no mandato anterior, uma vez que, em nome da continuidade das políticas nacionais, é esperado que, a cada troca de mandatário, a nova equipe mantenha o país em funciona- 
mento. Em caso de reeleição, o ocupante do cargo maior tem a possibilidade de cumprir o programado, porque dá continuidade a um plano que foi formulado por ele mesmo.

A Mensagem Presidencial abre o plano expondo ao país quais são os compromissos que o Governo assume, para então, nos anexos do Plano Plurianual, materializar a programação orçamentária, que devem, em princípio, guardar consonância entre si.

0 PPA em vigor foi elaborado em 2015, pela presidente Dilma, que assumiu seu segundo mandato em 2014. Este plano foi mantido pelo presidente Michel Temer após a cassação, em 31 de agosto de 2016, da presidente em exercício. 0 presidente eleito em outubro de 2018 executará o último ano de planejamento do governo anterior e terá até agosto de 2019 para preparar o seu PPA, que terá vigência de 2020 a 2023.

\section{Financiamento da educação}

O ciclo orçamentário que tem início com a edição do Plano Plurianual, que dita as regras para a composição dos orçamentos anuais, é a ferramenta que determina como se dará o financiamento da Educação Superior, composta por programas que abrangem a área pública $\mathrm{e}$ $\mathrm{a}$ área privada. Na medida em que estrutura a despesa pública, o plano define suas fontes de arrecadação, e somente permite sua aprovação se tais fontes existirem.

O objetivo principal dessa metodologia de planejamento é garantir as receitas necessárias à execução das despesas públicas, sem as quais os programas e ações de governo não são executados. Esta situação acontece em razão de o maior aporte de recursos para a manutenção da Educação Superior ter como origem a tributação, restando um pequeno percentual que se refere à arrecadação própria, o que significa que o Estado é o responsável por manter a educação no país, tendo em vista que o que é arrecadado pelas instituições públicas de educação superior, de forma direta, é muito pouco, conforme afirma Schwartzman (2002, p. 194) ao apontar que:

0 governo federal é o mantenedor de 39 universidades, 11 Faculdades e 11 Centros de Educação Tecnológica, num total de 482750 alunos de graduação, a sua grande maioria (459.011) nas Universidades. 0 governo federal é o seu principal mantenedor, já que nelas o ensino é gratuito e somente cerca de 3,5\% do orçamento global é constituído por recursos por elas diretamente arrecadados.

Segundo Castro (2001, p. 11), “a discussão a respeito do financiamento para a área de educação tem a ver com as condições materiais e com os recursos financeiros que viabilizam a formulação, implementação e avaliação das políticas", o que consolida a relação entre a programação orçamentária adequada e as mensagens presidenciais, para que sejam instituídas as políticas.

No Brasil, a determinação do financiamento pelo Estado surge na Constituição de 1934, quando foi tratada a questão da vinculação de receitas à educação, que, para Pinto e Adrião (2006, p. 25), "inaugura um procedimento que [...] perdura até hoje: a vinculação de um percentual mínimo da receita de impostos para ser aplicado em educação [...] que expressa, no contexto das políticas governamentais, certa priorização da educação."

Esse tratamento ao financiamento da educação é expresso na Constituição Federal atual, que determina, como forma de garantir um mínimo de fonte de financiamento, a aplicação de um percentual mínimo da arrecadação de receitas na educação, conforme seu artigo 212: “[...] a União aplicará anualmente, nunca menos de dezoito, e os Estados, o Distrito Federal e os Municípios vinte e cinco por cento, no mínimo, da receita resultante de impostos, compreendida a proveniente de transferências, na manutenção e desenvolvimento do ensino." (BRASIL, 1988).

Quanto a essa vinculação de recursos e à estrutura do financiamento da educação, Amaral (2018, p. 1) pontua que: 
A Constituição Federal de 1988 estabeleceu que a educação é um direito de todos e dever do Estado e da família e especificou os princípios sob os quais o ensino será ministrado. Foi estabelecida a gratuidade do ensino público e a autonomia das universidades; foram definidas as condições para a iniciativa privada atuar na área da educação; estabeleceu-se o papel a ser desempenhado pela União, Estados, Distrito Federal e Municípios na estruturação da educação nacional; vinculou recursos financeiros oriundos dos impostos a ser aplicados em educação e estabeleceu condições restritivas para os recursos públicos se dirigirem às instituições que não são públicas.

A Constituição Federal também trata da responsabilidade na concessão da educação superior pública em seu artigo 211 e parágrafos, cujo maior ônus é o da União, a quem cabe a manutenção da Instituições Federais de Educação:

A União, os Estados, o Distrito Federal e os Municípios organizarão em regime de colaboração seus sistemas de ensino.

§ 1o A União organizará o sistema federal de ensino e o dos Territórios, financiará as instituições de ensino públicas federais e exercerá, em matéria educacional, função redistributiva e supletiva, de forma a garantir equalização de oportunidades educacionais e padrão mínimo de qualidade do ensino mediante assistência técnica e financeira aos Estados, ao Distrito Federal e aos Municípios.

$\S 2$ o Os Municípios atuarão prioritariamente no ensino fundamental e na educação infantil.

$\S 3$ o Os Estados e o Distrito Federal atuarão prioritariamente no ensino fundamental e médio.

$\S 4^{\circ} \mathrm{Na}$ organização de seus sistemas de ensino, a União, os Estados, o Distrito Federal e os Municípios definirão formas de colaboração, de modo a assegurar a universalização do ensino obrigatório. (BRASIL, 1988).

A Constituição Federal de 1988 representou um avanço no que se refere ao financiamento da educação, uma vez que contemplou um aumento para as receitas vinculadas, ligando os valores arrecadados às despesas programadas a partir do estabelecimento de aplicações mínimas, pois
A CF de 1988, após um amplo debate sobre o financiamento da educação, aprovou alguns artigos em defesa dos recursos reservados à educação pública. A reserva de mínimos orçamentários vinculados à educação $(\mathrm{MDE})^{1}$ foi mantida, o que foi uma grande vitória, considerando que se cogitava a extinção das vinculações de impostos para despesas específicas. Dentre todas as vinculações pretendidas no Congresso Constituinte (saúde, previdência etc.), somente essa foi aprovada, o que demonstra o grau de prioridade dado à educação na Constituição. Houve, também, o incremento da vinculação destinada à União, que aumentou de $13 \%$ para $18 \%$, e mantiveram-se os quantitativos destinados aos Estados e Municípios. (CASTRO, 2001, p. 14).

Ainda que exista essa previsão constitucional, o financiamento da educação se apresenta como um desafio, tendo em vista a redução de investimento nas políticas públicas sociais, uma vez que

O financiamento da educação superior pública constitui-se num dos principais desafios para o Brasil, em face da adoção, a partir da década de 1990, de políticas de contenção de recursos com consequências comprometedoras na qualidade da produção do conhecimento e da formação de profissionais para o país. (AMARAL; CHAVES, 2014, p. 44).

O financiamento da educação superior ocorre a partir da arrecadação, e constituir as receitas suficientes para compô-la de forma que sejam suficientes para a execução de despesas públicas em educação superior é tarefa complexa e exige a estruturação das políticas públicas. Essa tarefa é realizada por intermédio dos instrumentos orçamentários: pelo Plano Plurianual, que estabelece prioridades e metas para quatro exercícios financeiros; pela Lei de Diretrizes Orçamentárias (LDO), que o faz para cada exercício financeiro; e pela Lei Orçamentária Anual que, pautada no PPA e na LDO, gerencia as receitas (estimativa) e despesas (fixação) de cada exercício financeiro.

1 Receitas vinculadas em Manutenção e Desenvolvimento do Ensino. 
O PPA e a LDO tratam do estabelecimento de metas e prioridades para as políticas públicas, que são materializadas a cada Lei Orçamentária Anual.

O primeiro passo para a compreensão do planejamento do governo é verificar como a educação superior é tratada nos Planos Plurianuais do Governo, tanto na Mensagem Presidencial, que traz a intenção de governo, quanto nos seus anexos, que consolidam a programação do orçamento.

\section{Mensagem presidencial e programação orçamentária no plano plurianual}

O planejamento das despesas públicas depende de autorização do Congresso Nacional e do Poder Executivo para a sua realização, organizada por ações orçamentárias que constam do Plano Plurianual, aberto pela Mensagem Presidencial de cada governante, e contempla diferentes funções, área de maior agregação das despesas governamentais, e subfunções, que representam um detalhamento dessas funções.

A programação orçamentaria é proposta pelos Poderes Legislativo, Executivo e Judiciário e encaminhada ao Poder Executivo, para a verificação de sua razoabilidade. ${ }^{2}$ Para assegurar a razoabilidade, o Poder Executivo compara os valores solicitados com aqueles aprovados e executados por cada Órgão Público nos exercícios anteriores, além de examinar as possibilidades de arrecadação de receitas públicas frente à solicitação de despesa, de forma a definir a proposta para cada exercício financeiro. Uma vez feito isso, esses instrumentos são submetidos à aprovação do Congresso

2 “O razoável é conforme a razão, racionável. Apresenta moderação, lógica, aceitação, sensatez. A razão enseja conhecer e julgar. Expõe o bom senso, a justiça, o equilíbrio. Promove a explicação, isto é, a conexão entre um feito e uma causa. É contraposto ao capricho, à arbitrariedade. Tem a ver com a prudência, com as virtudes morais, com o senso comum, com valores superiores propugnados em dada comunidade." (OLIVEIRA, 2003, p. 92).
Nacional e, por fim, sancionados pela Presidência da República.

A Mensagem Presidencial expressa as finalidades e pretensões do governo para o período, mas não define sua programação física e financeira, o que será feito nos anexos do PPA, no qual explicita os programas, os objetivos, o público-alvo, a regionalidade e o respectivo montante de recursos para o período, porque

Na mensagem presidencial encontram-se, basicamente, a análise dos cenário político, econômico, social e ambiental, a orientação estratégica para atuação e os recursos financeiros e os critérios utilizados em sua projeção; o projeto de lei contém o quadriênio abrangido pelo PPA, o conteúdo básico do plano, o encaminhamento para eventuais alterações nos programas, o prazo para envio de relatórios ao poder legislativo e a previsão da avaliação anual; já os anexos são formados pelo conjunto de programas e seus respectivos recursos previstos. (AMORIM, 2016, p. 54).

A Mensagem Presidencial compreende o diagnóstico da situação em que o país se encontra, mencionando as intenções de governo que serão materializadas no Plano Plurianual

O plano é amparado, legalmente, na Constituição Federal de 1988, no artigo 165, parágrafo $1^{\circ}$, enfatizando o estabelecimento de diretrizes que servirão de caminhos para a consecução das políticas públicas, bem como os objetivos relativos ao que se espera alcançar e as metas, que os traduzem em números para todo o PPA, detalhadas, até o período de 20082011, por exercício financeiro, que compõe o referido plano.

A composição do PPA foi alterada a partir de 2012, contemplando uma dimensão estratégica, na qual suas metas estão estabelecidas para o período total a que se refere o plano, não existindo o detalhamento por exercício financeiro.

O PPA é composto por diretrizes, objetivos e metas que refletem o planejamento governamental para o período, sendo estabelecidos os caminhos a serem seguidos, bem como o que se pretende realizar de forma descritiva e quantitativa, conforme segue: 
Diretrizes: linhas gerais de ação estipuladas em consonância com as políticas definidas, tendo em vista o atingimento dos macro-objetivos relacionados à materialização de tais políticas. As diretrizes balizam o caminho a ser percorrido num determinado período de tempo, com vistas a atingir os resultados mais expressivos visados pela ação governamental. Ex.: melhorar a educação e a rede de iluminação pública do município.

Objetivos: resultados concretos que se pretendem obter e manter por intermédio de um certo empreendimento considerado no seu global e não apenas em relação à parte que será executada num determinado ano. Ex.: ampliar a rede de energia elétrica, construção de novas escolas etc.

Metas: representa o desdobramento do objetivo em termos quantitativos dentro de um determinado período de tempo. Ex.: ampliar em 20\% a rede de energia elétrica, até o ano de 2007; construir em quatro anos 12 escolas municipais etc. (SILVA, 2012, p. 34).

O Plano Plurianual é uma referência para a execução do orçamento anual de cada ente da Federação e quantifica seus objetivos diretrizes e metas que deverão ser seguidos para a concretização deste plano maior de governo, demonstrados em leis específicas no período de 2004 a 2019, conforme segue:

PPA “Um Brasil de Todos”: Lei n 10.933, de 11 de agosto de 2004. Dispõe sobre o Plano Plurianual para o período 2004/2007 (BRASIL, 2004);

PPA "Desenvolvimento com Inclusão Social e Educação de Qualidade": Lei n ${ }^{\circ} 11.653$, de 7 de abril de 2008. Dispõe sobre o Plano Plurianual para o período 2008/2011 (BRASIL, 2008);

PPA “Plano Mais Brasil”: Lei n 12.593, de 18 de janeiro de 2012. Dispõe sobre o Plano Plurianual para o período 2012/2015 (BRASIL, 2012);

PPA "Desenvolvimento, Produtividade e Inclusão Social": Lei n 13.249, de 13 de janeiro de 2016. Dispõe sobre o Plano Plurianual para o período 2016/2019 (BRASIL, 2016).

A Mensagem Presidencial representa a pretensão do Governo e apresenta o compromisso político, que diante da composição do PPA deve ser a base para a programação do orçamento contido neste mesmo instrumento, como descrito:
Na mensagem presidencial encontram-se, basicamente, a análise dos cenários político, econômico, social e ambiental, a orientação estratégica para atuação e os recursos financeiros previstos e os critérios utilizados em sua projeção; o projeto de lei contém o quadriênio abrangido pelo PPA, o conteúdo básico do plano, o encaminhamento para eventuais alterações nos programas, o prazo para envio de relatórios ao poder legislativo e a previsão da avaliação anual; já os anexos são formados pelo conjunto de programas e seus respectivos recursos previstos. (AMORIM, 2016, p. 54).

$\mathrm{O}$ anexo relativo aos programas do Plano Plurianual estrutura o que foi dito pelo chefe do Poder Executivo na Mensagem Presidencial, de forma orçamentária, o que traduz o que pretende para os quatro exercícios compreendidos.

\section{Relação entre as mensagens presidenciais e a programação orçamentária no plano plurianual no período de 2004}

\section{a 2019}

A proposta política do Governo do Partido dos Trabalhadores (PT) tinha como um de seus principais focos a educação, como estabeleceram seus planos de governo para o período de 2004 a 2007, a exemplo de quando enfatiza que a "Educação [...] expressa com exatidão a prioridade que essa política pública terá no Governo Lula" (PARTIDO DOS TRABALHADORES, 2002, p. 1), e para 2008 a 2019:

Caberá ao segundo mandato avançar mais aceleradamente no rumo desse novo ciclo de desenvolvimento. Um desenvolvimento de longa duração, com redução das desigualdades sociais e regionais, respeito ao meio ambiente e à nossa diversidade cultural, emprego e bem-estar social, controle da inflação, ênfase na educação, democracia e garantia dos Direitos Humanos, presença soberana no mundo e forte integração continental. (PARTIDO DOS TRABALHADORES, 2006, p. 5).

[...] o PT afirma que há 'urgência para preparar os milhões de cientistas e técnicos que o 
desenvolvimento do país já está exigindo. Mas, principalmente, urgência para constituir uma cidadania que possa tomar em suas mãos o desenvolvimento econômico, político e cultural do país'. A candidatura de Dilma Rousseff defende a erradicação do analfabetismo, uma educação básica de qualidade e a expansão do ensino profissionalizante. (PARTIDO DOS TRABALHADORES, 2010, p. 1).

Fincando raízes na defesa intransigente da solidez macroeconômica, na continuidade e no fortalecimento das políticas sociais, e na busca permanente do crescimento econômico inclusivo e sustentável, promovendo a competitividade produtiva e assumindo a garantia de acesso à educação de qualidade como grande motor da transformação, o novo ciclo histórico que propomos ao Brasil passa pelas reformas política, federativa, urbana e dos serviços públicos. (PARTIDO DOS TRABALHADORES, 2014, p. 6).

Essa determinação é materializada no desenvolvimento de programas que foram mantidos ao longo do tempo em que o PT permaneceu no governo. Para tanto, foram desenvolvidos programas como o Bolsa Família, cuja contraprestação era a manutenção da criança na escola; o Programa de Erradicação do Trabalho Infantil (Peti), que também concedia bolsas a partir da frequência escolar; o Brasil Alfabetizado e Educação de Jovens e Adultos, que tinham como propósito combater o analfabetismo, voltado para os brasileiros acima de 15 anos, por intermédio de parcerias com organismos internacionais, universidades, escolas, Estados e Municípios; e o Programa Universidade para Todos (Prouni), que focava no acesso de estudantes de baixa renda à instituição de educação superior privada.

A menção a esses programas, de forma específica os relativos à Educação Superior, bem como sua programação orçamentária correlata, é o que se busca nos Planos Plurianuais a seguir. As ações orçamentárias para a Educação Superior são registradas nas tabelas de cada plano, sendo explicitadas aquelas que se associam ao compromisso político, às prioridades e aos procedimentos, mencionando-se as demais ações não relacionadas à Educação Superior constantes da programação orçamentária, para mostrar o volume de recursos investidos em temáticas que não constam na Mensagem Presidencial, além de enumerá-las com vistas à compreensão de cada assunto concernente às ações do orçamento.

\section{Plano Plurianual 2004-2007}

Em 2002 Lula foi eleito presidente e, ao assumir em 2003, executa o último exercício do PPA aprovado em 2000, ao mesmo tempo que prepara o Plano Plurianual para o período de 2004 a 2007. Por opção do novo governo, e em completa sintonia com a promessa feita na campanha de garantir ampla participação popular na definição das políticas públicas, a elaboração do PPA contou com apoio dos 26 Estados da Federação e do Distrito Federal, que asseguraram a participação da sociedade civil por meio de diversos encontros organizados em Fóruns de Participação Social. Naquele momento foram colocadas questões relacionadas aos caminhos que o país deveria seguir aos diferentes setores da sociedade. As respostas colhidas foram consolidadas pelo Ministério do Planejamento, Desenvolvimento e Gestão e resultaram na estruturação do PPA, denominado Brasil de Todos, bem mais estruturado que o anterior.

Considerados os objetivos de Governo constantes da Mensagem Presidencial do PPA 2004/2007, a Educação Superior está compreendida no objetivo "Ampliar o nível e a qualidade da escolarização da população, promovendo o acesso universal à educação" (BRASIL, 2003a, p. 78), quando se enfatiza a importância do acesso a este nível de ensino.

A Mensagem Presidencial (BRASIL, 2003a, p. 78) que encaminha o PPA 2004-2007 trata a educação como "O caminho para um projeto de futuro para o Brasil começa pela educação" e enfatiza que "Nos últimos anos, os principais avanços da educação brasileira referem-se à ampliação do acesso aos ensinos fundamental e médio e ao crescimento da matrícula no ensino superior". 
A leitura da Mensagem Presidencial e a identificação das informações relacionadas à Educação Superior brasileira demonstram a existência de 89 ações orçamentárias, mas que não se relacionam, necessariamente, às catego- rias eleitas (compromisso político, prioridades e procedimentos), conforme demonstra a Tabela 1, que também define o percentual de cada ação relacionada às categorias, dentro do total orçado.

Tabela 1 - Compromisso político, prioridades, procedimentos e programação orçamentária - PPA 2004-2007

\begin{tabular}{|c|c|c|c|c|}
\hline \multicolumn{2}{|r|}{ ITEM } & \multirow{2}{*}{$\begin{array}{l}\text { QUANTIDADE } \\
\text { DE AÇÕES } \\
\text { ORÇAMENTÁRIAS }\end{array}$} & \multirow[b]{2}{*}{ VALORES EM R\$ } & \multirow[b]{2}{*}{$\%$ APLICAD0 } \\
\hline CATEGORIA & DESCRIÇÃO & & & \\
\hline $\begin{array}{l}\text { Compromisso } \\
\text { político }\end{array}$ & $\begin{array}{l}\text { Ampliar o nível e a qualidade } \\
\text { da escolarização da população } \\
\text { promovendo o acesso universal à } \\
\text { educação }\end{array}$ & 22 & 6.420 .504 .778 & 19,05 \\
\hline Prioridade & $\begin{array}{l}\text { Relação estreita entre a } \\
\text { educação e as demandas do } \\
\text { mercado de trabalho }\end{array}$ & 1 & 79.236 .381 & 0,24 \\
\hline Prioridade & $\begin{array}{l}\text { Melhoria na qualidade das } \\
\text { ofertas da educação profissional } \\
\text { e superior em todo o país }\end{array}$ & 0 & 0 & 0 \\
\hline Prioridade & $\begin{array}{l}\text { Formação continuada de } \\
\text { professores }\end{array}$ & 3 & 466.503 .457 & 1,38 \\
\hline Prioridade & $\begin{array}{l}\text { Esporte na educação superior } \\
\text { para redução de riscos sociais }\end{array}$ & 0 & 0 & 0 \\
\hline Procedimento & $\begin{array}{l}\text { Oferta de educação profissional, } \\
\text { tecnológica e universitária }\end{array}$ & 0 & 0 & 0 \\
\hline Procedimento & $\begin{array}{l}\text { Programa Democratizando o } \\
\text { Acesso à Educação Profissional, } \\
\text { Tecnológica e Universitária }\end{array}$ & 0 & 0 & 0 \\
\hline \multirow[t]{3}{*}{ Procedimento } & $\begin{array}{l}\text { Programa Universidade do } \\
\text { século XXI }\end{array}$ & 0 & 0 & 0 \\
\hline & $\begin{array}{l}\text { Programa Valorização e } \\
\text { Formação de Professores e } \\
\text { Trabalhadores da Educação }\end{array}$ & 0 & 0 & 0 \\
\hline & Programa Segundo Tempo & 0 & 0 & 0 \\
\hline \multicolumn{2}{|r|}{ TOTAL } & 26 & 6.966 .244 .616 & 20,67 \\
\hline \multicolumn{2}{|c|}{ Total para a Educação Superior no PPA 2004-2007 } & 89 & 33.703 .490 .649 & 100,00 \\
\hline
\end{tabular}

Fonte: Brasil (2003b).

Como se percebe na Tabela 1, a prioridade Esporte na Educação Superior para redução de riscos sociais, cujo procedimento constante da Mensagem Presidencial é o Programa Segundo
Tempo, não recebeu dotação orçamentária no PPA 2004-2007.

O orçamento restante para a educação superior, não identificado na Tabela 1, por não ter 
relação com o compromisso político, as prioridades e os procedimentos estabelecidos pelo governo no PPA, somam outras 63 ações que se referem: à manutenção da educação superior, que compreendem a construção de novos prédios e as despesas relacionadas aos cursos de graduação e pós-graduação; à avaliação das instituições de ensino superior; à pesquisa; à internacionalização; ao apoio ao estudante; às contribuições a IES internacionais; à educação especial; e aos serviços à comunidade.

A manutenção da educação superior reúne o maior quantitativo de ações e de dotação orçamentária, 36 ações no PPA, dentre as 63 que não atendem o que dita a Mensagem Presidencial, que totalizam $\mathrm{R} \$ 25.996 .265 .813,00$ (vinte e cinco bilhões, novecentos e noventa e seis milhões, duzentos e sessenta e cinco mil e oitocentos e trezes reais), $77,1 \%$ de todo o orçamento para a educação superior no período, o que compromete o atendimento das categorias elencadas na Mensagem Presidencial.

0 restante das 27 ações relativas à Educação Superior, mas que não se referem ao elencado na Mensagem Presidencial (BRASIL, 2003a), totaliza 2,2\% do total orçado para a educação superior no PPA 2004-2007, que somam R \$ 740.980.220,00, assim distribuídos:

19 ações para contribuições a IES internacionais: $\mathrm{R} \$ 285.443 .815,00$;

2 ações de apoio ao estudante: $\mathrm{R} \$ 227.701 .585,00$;

2 ações para pesquisa: $\mathrm{R} \$ 134.262 .106,00$;

1 ação para serviços à comunidade: R\$ 75.562.973,00;

2 ações de internacionalização: $\mathrm{R} \$ 13.363 .200,00$;

1 ação relacionada à educação especial: $\mathrm{R} \$$ 4.646.541,00.

Chama atenção neste PPA, o primeiro elaborado sob auspício do Partido dos Trabalhadores, eleito em 2002, derrotando uma política neoliberal implementada pelo governo anterior, que, mesmo cumprindo a promessa da ampla participação popular, ao concretizar o orçamento nacional, apenas $20,67 \%$ dos valores programados correspondem ao conteúdo da Mensagem Presidencial, em conformidade com o compromisso político, a prioridade e as ações observadas no que se refere à educação superior, conforme o total da Tabela 1.

\section{Plano Plurianual 2008-2011}

Em 2007, Lula, eleito em 2006, é reconduzido à Presidência do Brasil, sendo, portanto, o mesmo partido e o mesmo governante responsável pela elaboração do PPA para o período de 2008 a 2011, representando a continuidade, confirmada na manutenção de ações e metodologia adotadas para a execução da despesa pública, entre estas, em educação superior.

O Plano Plurianual Desenvolvimento com Inclusão Social e Educação de Qualidade explicita, inicialmente, na Mensagem Presidencial no 650 (BRASIL, 2007a, p. 9) que “O PPA 2008/2011 organiza as ações do Governo em três eixos: crescimento econômico, agenda social e educação de qualidade".

Para o alcance da educação de qualidade foi estabelecido como caminho o Plano de Desenvolvimento da Educação (PDE), aliado ao Programa Universidade para Todos (Prouni), no que se refere à educação superior:

O Plano de Desenvolvimento da Educação (PDE) é elemento essencial dessa estratégica. Com o PDE, pretendemos construir o início de um novo tempo, capaz de assegura a primazia do talento sobre a origem social e prevalência do mérito sobre a riqueza familiar. A busca pela melhoria da qualidade da educação representa a conjugação os esforços das Unidades da Federação atuando em regime de colaboração com as famílias e a comunidade. Os investimentos e educação serão complementados com o Programa Universidade para Todos (Prouni) e a adoção da proposta de reestruturação das universidades federais, além de ampliar e modernizar o ensino profissionalizante, instalando escolas técnicas em todas as cidades-polo do País. (BRASIL, 2007a, p. 9).

Na análise da Mensagem Presidencial, somada ao levantamento orçamentário, a partir dos parâmetros de compromisso político, prioridades e procedimentos definidos, resultou no que consta na Tabela 2 . 
Tabela 2 - Compromisso político, prioridades, procedimentos e programação orçamentária - PPA 2008-2011

\begin{tabular}{|c|c|c|c|c|}
\hline \multicolumn{2}{|r|}{ ITEM } & \multirow{2}{*}{$\begin{array}{l}\text { QUANTIDADE } \\
\text { DE AÇÕES } \\
\text { ORÇAMENTÁRIAS }\end{array}$} & \multirow{2}{*}{$\begin{array}{l}\text { VALORES } \\
\text { EM R\$ }\end{array}$} & \multirow{2}{*}{$\begin{array}{c}\% \\
\text { APLICADO }\end{array}$} \\
\hline CATEGORIA & DESCRIÇÃO & & & \\
\hline $\begin{array}{l}\text { Compromisso } \\
\text { político }\end{array}$ & Crescimento econômico & 0 & 0 & 0,00 \\
\hline $\begin{array}{l}\text { Compromisso } \\
\text { político }\end{array}$ & Agenda social & 0 & 0 & 0,00 \\
\hline $\begin{array}{l}\text { Compromisso } \\
\text { político }\end{array}$ & Educação de qualidade & 1 & 160.062 .901 & 0,20 \\
\hline $\begin{array}{l}\text { Compromisso } \\
\text { político }\end{array}$ & $\begin{array}{l}\text { Democratização de acesso ao } \\
\text { ensino superior }\end{array}$ & 75 & 1.356 .101 .454 & 1,66 \\
\hline $\begin{array}{l}\text { Compromisso } \\
\text { político }\end{array}$ & $\begin{array}{l}\text { Recuperação da universidade } \\
\text { pública }\end{array}$ & 65 & 5.529 .323 .881 & 6,76 \\
\hline Prioridade & $\begin{array}{l}\text { Plano de Desenvolvimento da } \\
\text { Educação (PDE) }\end{array}$ & 0 & 0 & 0,00 \\
\hline Prioridade & $\begin{array}{l}\text { Propiciar o acesso da população } \\
\text { brasileira à educação e ao } \\
\text { conhecimento com equidade, } \\
\text { qualidade e diversidade }\end{array}$ & 0 & 0 & 0,00 \\
\hline Prioridade & $\begin{array}{l}\text { Fortalecer o papel da União } \\
\text { como mantenedora das } \\
\text { importantes redes de educação } \\
\text { técnica e superior }\end{array}$ & 0 & 0 & 0,00 \\
\hline Prioridade & $\begin{array}{l}\text { Fortalecer o papel da União } \\
\text { como normatizadora e } \\
\text { reguladora dos sistemas }\end{array}$ & 0 & 0 & 0,00 \\
\hline Prioridade & $\begin{array}{l}\text { Corrigir as distorções e } \\
\text { desequilíbrios regionais }\end{array}$ & 0 & 0 & 0,00 \\
\hline Prioridade & $\begin{array}{l}\text { Reforçar a atuação da União } \\
\text { como indutora de políticas e } \\
\text { inovações }\end{array}$ & 0 & 0 & 0,00 \\
\hline Prioridade & $\begin{array}{l}\text { Reforçar a atuação da União } \\
\text { como avaliadora de processos e } \\
\text { resultados }\end{array}$ & 0 & 0 & 0,00 \\
\hline Prioridade & $\begin{array}{l}\text { Apoiar a pesquisa com bolsas de } \\
\text { pós-doutorado }\end{array}$ & 0 & 0 & 0,00 \\
\hline Procedimento & $\begin{array}{l}\text { Programa Universidade para } \\
\text { Todos }\end{array}$ & 0 & 0 & 0,00 \\
\hline Procedimento & $\begin{array}{l}\text { Reestruturação das } \\
\text { universidades federais }\end{array}$ & 0 & 0 & 0,00 \\
\hline Procedimento & $\begin{array}{l}\text { Ampliação e modernização do } \\
\text { ensino profissionalizante com } \\
\text { escolas técnicas em todas as } \\
\text { cidades-polo do país }\end{array}$ & 0 & 0 & 0,00 \\
\hline Procedimento & $\begin{array}{l}\text { Investimentos públicos para } \\
\text { estimular o acesso à Instituição } \\
\text { de Ensino Superior Privada } \\
\text { (PROUNI) }\end{array}$ & 2 & 6.869 .369 .045 & 8,39 \\
\hline
\end{tabular}




\begin{tabular}{|c|c|c|c|c|}
\hline Procedimento & $\begin{array}{l}\text { Interiorização da universidade } \\
\text { pública }\end{array}$ & 0 & 0 & 0,00 \\
\hline Procedimento & Programa Brasil Universitário & 0 & 0 & 0,00 \\
\hline Procedimento & $\begin{array}{l}\text { Programa Acessibilidade nas } \\
\text { Universidades }\end{array}$ & 0 & 0 & 0,00 \\
\hline Procedimento & $\begin{array}{l}\text { Programa Nacional de Pós- } \\
\text { Doutorado }\end{array}$ & 0 & 0 & 0,00 \\
\hline Procedimento & $\begin{array}{l}\text { Plano Nacional de Políticas para } \\
\text { Mulheres }\end{array}$ & 0 & 0 & 0,00 \\
\hline Procedimento & $\begin{array}{l}\text { Contribuição do país para o } \\
\text { desenvolvimento da região do } \\
\text { Mercosul }\end{array}$ & 0 & 0 & 0,00 \\
\hline & TOTAL & 143 & 13.914 .857 .281 & 17,01 \\
\hline
\end{tabular}

Fonte: Brasil (2007b).

Considerada a programação orçamentária, foram encontradas no PPA 2008-2011 165 ações referentes à Educação Superior. Essas ações foram classificadas em conformidade com seus conteúdos, de forma a verificar sua correspondência com o compromisso político, as prioridades e os procedimentos constantes da respectiva Mensagem Presidencial, percebendo-se essa relação com 143 ações orçamentárias.

O Plano de Desenvolvimento da Educação (PDE) foi considerado como prioridade no PPA 2008-2011, e, em relação à educação superior, está apoiado em três pilares: a reestruturação das universidades federais, a democratização do acesso à educação superior e a avaliação. 0 primeiro e segundo pilares reúnem um montante de R \$ 6.869.369.045,00 (seis bilhões, oitocentos e sessenta e nove milhões, trezentos e sessenta e nove mil e quarenta e cinco reais), representando 8,4\% do total programado para a educação superior, enquanto o terceiro (avaliação) não tem ações orçamentárias definidas no PPA 2008-2011.

A mensagem destaca que:

A ampliação do acesso ao ensino superior, bem como a possibilidade de reestruturar o sistema universitário federal, como ações do PDE, só adquirem plenamente sentido quando vislumbradas como elos adicionais de um conjunto de projetos no âmbito da educação superior que articulam, com um olho na educação básica e outro na pós-graduação, ampliação de acesso e permanência, reestruturação acadêmica, recuperação orçamentária, avaliação e regulação, concorrendo para que a universidade, para além da formação profissional e técnica, cumpra a função de criar, difundir e popularizar as ciências e as artes. (BRASIL, 2007a, p. 31).

$\mathrm{Na}$ Mensagem Presidencial relativa à Educação Superior, a segunda prioridade, conforme descrito na Tabela 2, se relaciona ao acesso da população brasileira à educação, cuja programação orçamentária é a mesma do compromisso político de acesso à educação, motivo pelo qual essas 75 ações previstas são registradas, na Tabela 2, no compromisso político para não contarem em duplicidade e somam R \$1.356.101.454 (um bilhão, trezentos e cinquenta e seis milhões, centro e um mil e quatrocentos e cinquenta e quatro reais), significando 1,66\% do orçamento para a educação superior no PPA.

A correção de desequilíbrios educacionais regionais tem seu lugar na interiorização das universidades pelo país, além da instalação de campus nessas cidades, que já foram mencionadas no acesso à educação - compromisso político - e totalizam 72 ações orçamentárias com $\mathrm{R} \$ 1.342 .741 .889,00$ (um bilhão, trezentos e quarenta e dois milhões, setecentos e quarenta e um mil e oitocen- 
tos e oitenta e nove reais), que guardam correspondência com os procedimentos da Mensagem Presidencial, Interiorização da Universidade Pública, que equivalem a 1,64\% do total orçado.

As outras prioridades da Mensagem Presidencial não têm relação direta com ações orçamentárias constantes do PPA, razão pela qual não têm valores atribuídos na Tabela 2: fortalecer o papel da União como mantenedora das importantes redes de educação técnica e superior; fortalecer o papel da União como normatizadora e reguladora dos sistemas; reforçar a atuação da União como avaliadora de processos e resultados; e apoiar a pesquisa com bolsas de pós-doutorado.

As ações orçamentárias Programa Universidade para Todos e Investimentos públicos para estimular o acesso à Instituição de Educação Superior Privada (PROUNI) estão compreendidas na prioridade relacionada ao PDE, assim como a ação Reestruturação das Universidades se associa ao compromisso político com o mesmo nome, já mencionado anteriormente, não sendo registradas novamente para não gerarem uma dupla contagem.

As ações seguintes foram apenas mencionadas na Mensagem Presidencial (BRASIL, 2007a), mas não tiveram correspondência com as ações na programação orçamentária do PPA:

Ampliação e modernização do ensino profissionalizante com escolas técnicas em todas as cidades-polo do país;

Programa Acessibilidade nas Universidades;

Programa Nacional de Pós-Doutorado;

Plano Nacional de Políticas para as Mulheres;

Contribuição do país para o desenvolvimento da região do Mercosul.

O Plano Plurianual 2008-2011, relativo à continuidade do presidente Lula e, portanto, do Partido dos Trabalhadores no governo tinha como uma de suas frentes o Plano de Desenvolvimento da Educação (PDE), percebendo-se, portanto, que a relação entre a programação orçamentária e o que foi dito na Mensagem
Presidencial passou a ser de 17,0\%, menor que o PPA anterior, de 20,67\%, o que revela a intenção do governo no planejamento de políticas relativas à Educação Superior, com um menor investimento no que se pretendia na Mensagem Presidencial e o atendimento de questões básicas da educação superior, como sua manutenção.

\section{Plano Plurianual 2012-2015}

Nos exercícios de 2012 a 2015, ocorre a permanência do governo PT no poder, sendo o respectivo Plano Plurianual elaborado pela presidente Dilma Rousseff, eleita em 2010.

Em 2011, o Ministério do Planejamento, Desenvolvimento e Gestão apresenta uma nova forma de programação desse plano, com vistas ao aprimoramento. Segundo Santos, Ventura e Neto (2015, p. 71), este novo PPA "apresentou inovações significativas na sua estrutura e linguagem, com o objetivo declarado de representar melhor as escolhas e as políticas públicas, além de criar condições mais adequadas para a sua gestão".

O PPA 2012-2015 não evidencia a educação como prioridade no seu título, ao defini-lo como "Plano Mais Brasil - Mais Desenvolvimento, Mais Igualdade, Mais Participação", ressaltando, na sua visão de futuro, a necessidade da educação com qualidade, do conhecimento e da tecnologia, a exemplo do PPA anterior, pois, " trabalharemos para que o Brasil seja um país reconhecido: Por seu modelo de desenvolvimento sustentável, bem distribuído regionalmente, que busca a igualdade social com educação de qualidade, produção de conhecimento, inovação tecnológica [...]" (BRASIL, 2011a, p. 17)

A análise da Mensagem Presidencial, selecionando-se do seu conteúdo o compromisso político, as prioridades e os procedimentos, confrontados com as ações orçamentárias da programação orçamentária relativa à Educação Superior Brasileira, é evidenciada na Tabela 3. 
Tabela 3 - Compromisso político, prioridades, procedimentos e programação orçamentária - PPA 2012-2015

\begin{tabular}{|c|c|c|c|c|}
\hline \multicolumn{2}{|r|}{ ITEM } & \multirow{2}{*}{$\begin{array}{c}\text { QUANTIDADE } \\
\text { DE AÇÕES } \\
\text { ORÇAMENTÁRIAS }\end{array}$} & \multirow{2}{*}{$\begin{array}{l}\text { VALORES } \\
\text { EM R\$ }\end{array}$} & \multirow{2}{*}{$\begin{array}{c}\% \\
\text { APLICADO }\end{array}$} \\
\hline CATEGORIA & DESCRIÇÃO & & & \\
\hline $\begin{array}{l}\text { Compromisso } \\
\text { político }\end{array}$ & Desenvolvimento sustentável & 0 & 0 & 0,00 \\
\hline $\begin{array}{l}\text { Compromisso } \\
\text { político }\end{array}$ & $\begin{array}{l}\text { Distribuição regional de } \\
\text { recursos }\end{array}$ & 0 & 0 & 0,00 \\
\hline $\begin{array}{l}\text { Compromisso } \\
\text { político }\end{array}$ & $\begin{array}{l}\text { Igualdade social com educação } \\
\text { de qualidade, produção de } \\
\text { conhecimento e inovação } \\
\text { tecnológica }\end{array}$ & 0 & 0 & 0,00 \\
\hline $\begin{array}{l}\text { Compromisso } \\
\text { político }\end{array}$ & Educação para inclusão social & 0 & 0 & 0,00 \\
\hline $\begin{array}{l}\text { Compromisso } \\
\text { político }\end{array}$ & $\begin{array}{l}\text { Papel da educação no } \\
\text { aprofundamento da redução } \\
\text { de desigualdades sociais e } \\
\text { regionais no Brasil, sendo } \\
\text { fator de promoção da inclusão } \\
\text { numa sociedade que valoriza } \\
\text { crescentemente o conhecimento } \\
\text { como dimensão da cidadania, } \\
\text { da igualdade social e do } \\
\text { desenvolvimento sustentável }\end{array}$ & 0 & 0 & 0,00 \\
\hline Prioridade & $\begin{array}{l}\text { Expansão de matrículas na } \\
\text { educação superior }\end{array}$ & 18 & 13.354.847.189 & 12,95 \\
\hline Prioridade & Formação de mão de obra & 10 & 387.650 .786 & 0,38 \\
\hline Prioridade & $\begin{array}{l}\text { Ampliação de gastos em } \\
\text { educação sobre o PIB }\end{array}$ & 0 & 0 & 0,00 \\
\hline Prioridade & $\begin{array}{l}\text { Expansão da rede profissional e } \\
\text { tecnológica e da rede federal da } \\
\text { educação superior }\end{array}$ & 0 & 0 & 0,00 \\
\hline Prioridade & Cumprimento de metas do PNE & 0 & 0 & 0,00 \\
\hline Procedimento & PRONATEC & 0 & 0 & 0,00 \\
\hline Procedimento & Fomento à pesquisa e extensão & 3 & 2.361 .721 .126 & 2,29 \\
\hline Procedimento & $\begin{array}{l}\text { Aumento do número de mestres } \\
\text { e doutores }\end{array}$ & 0 & 0 & 0,00 \\
\hline Procedimento & $\begin{array}{l}\text { Expansão do número de } \\
\text { matrículas na educação } \\
\text { superior }\end{array}$ & 0 & 0 & 0,00 \\
\hline Procedimento & $\begin{array}{l}\text { Acesso ao ensino superior } \\
\text { onde a oferta é reduzida - } \\
\text { interiorização }\end{array}$ & 0 & 0 & 0,00 \\
\hline Procedimento & $\begin{array}{l}\text { Elevar o número de campi da } \\
\text { Rede Federal de Educação } \\
\text { Superior para } 321\end{array}$ & 0 & 0 & 0,00 \\
\hline Procedimento & $\begin{array}{l}\text { Elevar o número de campi das } \\
\text { Universidades Federais para } 63\end{array}$ & 0 & 0 & 0,00 \\
\hline Procedimento & $\begin{array}{l}\text { Educação superior para } \\
\text { inovação tecnológica }\end{array}$ & 0 & 0 & 0,00 \\
\hline
\end{tabular}




\begin{tabular}{|c|c|c|c|c|}
\hline Procedimento & $\begin{array}{l}\text { Educação superior para oferta } \\
\text { de mão de obra qualificada }\end{array}$ & 0 & 0 & 0,00 \\
\hline Procedimento & $\begin{array}{l}\text { Dobrar o número de doutores e } \\
\text { mestre, mantendo a formação } \\
\text { anual de } 12 \text { mil doutores }\end{array}$ & 0 & 0 & 0,00 \\
\hline Procedimento & Concessão de bolsas de estudo & 5 & 17.470 .366 .839 & 16,94 \\
\hline Procedimento & $\begin{array}{l}\text { Concessão de financiamentos } \\
\text { estudantis }\end{array}$ & 2 & 5.108 .358 .919 & 4,95 \\
\hline Procedimento & $\begin{array}{l}\text { Maior oferta de cursos de } \\
\text { qualidade nas diversas áreas e } \\
\text { disciplinas acadêmicas }\end{array}$ & 2 & 83.882 .922 & 0,08 \\
\hline Procedimento & $\begin{array}{l}\text { Concessão de bolsas por } \\
\text { agências federais e estaduais de } \\
\text { fomento à pesquisa }\end{array}$ & 0 & 0 & 0,00 \\
\hline Procedimento & $\begin{array}{l}\text { Inclusão social: ampliar } \\
\text { a participação de grupos } \\
\text { historicamente excluídos } \\
\text { (negros e índios) na educação } \\
\text { superior }\end{array}$ & 0 & 0 & 0,00 \\
\hline Procedimento & Elevação de taxas de matrículas & 0 & 0 & 0,00 \\
\hline Procedimento & $\begin{array}{l}\text { Elevação do número de mestres } \\
\text { e doutores no corpo docente } \\
\text { das universidades }\end{array}$ & 0 & 0 & 0,00 \\
\hline Procedimento & $\begin{array}{l}\text { Aprimoramento dos } \\
\text { instrumentos de avaliação da } \\
\text { qualidade do ensino superior }\end{array}$ & 3 & 473.527 .357 & 0,46 \\
\hline & TOTAL & 39 & 34.048 .113 .297 & 33,01 \\
\hline \multicolumn{2}{|c|}{$\begin{array}{l}\text { TOTAL PARA A EDUCAÇÃO SUPERIOR NO PPA } \\
\text { 2012-2015 }\end{array}$} & 47 & 103.135 .924 .174 & 100,00 \\
\hline
\end{tabular}

Fonte: Brasil (2011b).

A busca pela programação orçamentária no Anexo do PPA encontrou 47 ações orçamentárias, que foram classificadas em conformidade com os itens compromisso político, prioridades e procedimentos pertinentes ao PPA 20122015. Os compromissos políticos constantes deste PPA não estão explicitados no orçamento por intermédio de suas ações orçamentárias.

A expansão de matrículas na educação superior, prioridade do governo, cujo aporte de recursos agrega a expansão da rede profissional e tecnológica e da rede federal da Educação Superior, outra prioridade deste PPA, foi contemplada com dezoito ações orçamentárias, constantes do PPA, cujo total destinado foi de $\mathrm{R} \$$ 13.354.847.189,00 (treze bilhões, trezentos e cinquenta e quatro milhões, oitocentos e quarenta e sete mil e cento e oitenta e nove reais), equivalentes a 12,95\% da programação para a Educação Superior no PPA.

A prioridade seguinte está correlacionada à formação de mão de obra, para a qual foram identificadas dez ações que somaram $\mathrm{R} \$ 387.650 .786,00$ (trezentos e oitenta e sete milhões, seiscentos e cinquenta mil, setecentos e oitenta e seis reais), 0,38\% do total da Educação Superior. Algumas dessas ações compreendem finalidades específicas que também se associam à prioridade da elevação do número de mestres e doutores no corpo docente das universidades, assim como à ação de dobrar o número de doutores, anualmente.

Considerando ainda as prioridades, a ampliação de gastos em educação em relação ao PIB, uma das prioridades constantes na Tabela 3, é observada, ainda que indiretamente, tendo 
em vista que houve um aumento no total destinado à Educação Superior neste PPA, comparativamente ao PPA 2008-2011, de 26,03\%.

A última prioridade estabelecida para este PPA é o cumprimento das metas do PNE, que se relacionam com as ações orçamentárias constantes da sua programação. As metas, para a educação superior, fazem a previsão tanto do aumento das taxas de matrículas, como assumem o compromisso com a qualidade e ainda com os investimentos na pós-graduação nacional e na carreira profissional, conforme segue:

Meta 12: elevar a taxa bruta de matrícula na educação superior para 50\% (cinquenta por cento) e a taxa líquida para 33\% (trinta e três por cento) da população de 18 (dezoito) a 24 (vinte e quatro) anos, assegurada a qualidade da oferta e expansão para, pelo menos, $40 \%$ (quarenta por cento) das novas matrículas, no segmento público. (BRASIL, 2014, p. 41);

Meta 13: elevar a qualidade da educação superior e ampliar a proporção de mestres e doutores do corpo docente em efetivo exercício no conjunto do sistema de educação superior para $75 \%$ (setenta e cinco por cento), sendo, do total, no mínimo, 35\% (trinta e cinco por cento) doutores. (BRASIL, 2014, p. 43);

Meta 14: elevar gradualmente o número de matrículas na pós-graduação stricto sensu, de modo a atingir a titulação anual de 60.000 (sessenta mil) mestres e 25.000 (vinte e cinco mil) doutores. (BRASIL, 2014, p. 46);

Meta 18: assegurar, no prazo de 2 (dois) anos, a existência de planos de Carreira para os (as) profissionais da educação básica e superior pública de todos os sistemas de ensino e, para o plano de Carreira dos (as) profissionais da educação básica pública, tomar como referência o piso salarial nacional profissional, definido em lei federal, nos termos do inciso VIII do art. 206 da Constituição Federal. (BRASIL, 2014, p. 56).

A primeira ação constante do PPA 20122015 é o PRONATEC, ${ }^{3}$ que para Lima e Pacheco (2017, p. 499) “[...] apareceu como política de

3 O Programa Nacional de Acesso ao Ensino Técnico e Emprego (Pronatec) foi criado pelo Governo Federal em 2011, por meio da Lei no 12.513 , com a finalidade de ampliar a oferta de cursos de Educação Profissional e Tecnológica (EPT), por meio de programas, projetos e ações de assistência técnica e financeira. governo implantada em 2011 que fomentou a destinação de recursos públicos às entidades privadas", não sendo possível aliar, de forma direta, uma ação orçamentária da programação deste PPA ao PRONATEC.

A ação seguinte da Mensagem Presidencial deste PPA é o fomento à pesquisa e extensão, expresso em três ações do orçamento (Fomento às Ações de Graduação, Pós-Graduação, Ensino Pesquisa e Extensão e duas ações de Ensino e Pesquisa de Graduação em Estatística e Geociências), que totalizaram $\mathrm{R} \$ 2.361 .721 .126,00$ (dois bilhões, trezentos e sessenta e um milhões, setecentos e vinte e um mil e cento e vinte e seis reais), o equivalente a $2,29 \%$ do total aprovado para este PPA.

0 acesso à educação superior, com foco na interiorização, é a próxima ação constante da MP, que associa a ação de elevar o número de campi da Rede Federal de Educação Superior para 321, reconhecidas em 11 ações, à prioridade expansão de matrículas, já mencionada, cujo total foi R\$755.157.871 (setecentos e cinquenta e cinco milhões, cento e cinquenta e sete mil e oitocentos e setenta e um reais), $0,73 \%$ do total programado para a educação superior. A interiorização das universidades federais, além de melhorar o acesso à educação superior, gera desenvolvimento para a região em que se instala na medida em que mais pessoas permanecerão na localidade, pois, como lembra Jesus (2016, p. 36), “de maneira prática, a chegada de uma universidade pública implica na contratação de servidores (professores e técnicos) e alunos da microrregião (a depender dos cursos ofertados) que provavelmente irão residir no local", e destaca o autor que "economicamente mais dinheiro estará circulando na economia local, novas moradias e restaurantes, qualificação da rede hoteleira, padarias, farmácias e supermercados."

A concessão de bolsas de estudo é identificada em cinco ações orçamentárias, que somam $\mathrm{R} \$$ 17.470.366.839,00 (dezessete bilhões, quatrocentos e setenta milhões, trezentos e sessenta e seis mil e oitocentos e trinta e nove reais) e 
correspondem a 16,94\% do total alocado para a Educação Superior no PPA 2012-2015.

A última ação elencada a partir da Mensagem Presidencial diz respeito ao aprimoramento dos instrumentos de avaliação da qualidade de ensino superior, que foi percebida em três ações da programação do PPA, que resultam em $\mathrm{R} \$ 473.527 .357,00$ (quatrocentos e setenta e três milhões, quinhentos e vinte e sete mil e trezentos e cinquenta e sete reais), equivalente a $0,46 \%$ do que foi destinado à Educação Superior.

A preocupação em avaliar a educação superior tem sido crescente, tendo em vista a expansão das vagas com o compromisso e a necessidade de mensurar a qualidade do ensino.

Frente à intensificação dos debates em torno da qualidade da educação nos mais diversos níveis e modalidades de ensino, a avaliação consolida-se entre as mais significativas modificações no cenário educacional nos últimos anos. Seguindo uma forte tendência internacional, essa realidade impacta fortemente a organização e o planejamento das metas governamentais relacionadas à educação brasileira, a qual passa a utilizar massivamente alguns indicadores quantitativos voltados ao diagnóstico do sistema educacional, em diversos âmbitos (CERUTTI et al, 2011).

Algumas ações constantes da Mensagem Presidencial (BRASIL, 2011a) não encontram correspondência, de forma direta, nas ações programadas no PPA 2012-2015:

Educação superior para inovação tecnológica;

Concessão de bolsas por agências federais e estaduais de fomento à pesquisa;

Inclusão social como forma de ampliar a participação de grupos historicamente

excluídos (negros e índios) na educação superior;

PRONATEC;

A concessão de financiamento estudantil.

O restante da programação orçamentária do PPA se relaciona à Manutenção da Educação Superior, somando R \$ 69.087.810.877 (sessenta e nove bilhões, oitenta e sete milhões, oitocentos e dez mil e oitocentos e setenta e sete reais), que equivalem a $66,99 \%$ do total destinado à Educação Superior no PPA 2012-2015, representadas por seis ações orçamentárias, ressaltando-se que, como no PPA anterior, é o maior aporte de valores.

O PPA 2012-2015 é calcado em 10 objetivos de governo que promovem uma relação mais focada com as ações, conteúdo da programação orçamentária, o que estreitou a relação entre o plano de governo e as políticas públicas, o que, na educação superior, teve como consequência um alinhamento entre o que foi dito na Mensagem Presidencial e o que foi programado no PPA de 33,01\%.

Ainda que não tenha ocorrido a totalidade de aderência entre o que foi dito na Mensagem Presidencial e o que foi programado no PPA, o governo do PT revela um maior comprometimento no que se refere à educação superior no Brasil, tendo em vista a crescente demonstrada de $96,51 \%$ maior que o que foi percebido no PPA 2008-2011 (vinculação de 17\%).

\section{Plano Plurianual 2016-2019}

O Plano Plurianual 2016-2019 é caracterizado pela continuidade do PT no governo e também da presidente Dilma, que foi reeleita em 2014, sendo considerado inovador pela Administração Pública, em relação aos anteriores, em razão da dimensão estratégica adotada na sua elaboração, que detalha as prioridades e metas do governo apenas na Lei de Diretrizes Orçamentárias, dando foco aos programas de governo e aos resultados esperados destes programas, considerado um avanço, relativamente ao PPA anterior, pois

Também convém destacar que, nesse PPA, optou-se por relacionar cada programa aos produtos que ele se propõe a gerar, independentemente das ações a serem implementadas para tanto. Essa opção tem, pelo menos, duas consequências importantes: torna mais transparentes os resultados dos programas, as formas de medi-los e o estabelecimento de suas metas; e retira do PPA parte daquele detalhamento 
excessivo que se mencionou anteriormente. Além disso, ao fazê-lo, dá novo status à Lei de Diretrizes Orçamentárias (LDO), que passa a ser o instrumento legal que define as metas a serem buscadas a cada ano de vigência do PPA. (FERREIRA; SANTOS; SOUSA, 2016, p. 89).

A atenção dada à Educação Superior no Plano "Desenvolvimento, Produtividade e Inclusão Social" permanece na expansão de vagas e democratização do acesso, na viabilização de estudos nas instituições privadas, com contribuição do financiamento público, além de objetivar a internacionalização com foco na tecnologia e na qualidade (BRASIL, 2015a, p. 28).

O levantamento do compromisso político, prioridades e metas resultou no que se apresenta na Quadro 1, não sendo possível, em razão da dimensão estratégica e deste PPA estar em andamento, o levantamento dos valores das ações orçamentárias, pois essas são definidas a cada exercício financeiro, mediante a programação orçamentária constante da Lei Orçamentária Anual.

Quadro 1 - Compromisso político, prioridades e ações - Mensagem Presidencial 2016-2019

\begin{tabular}{|c|l|}
\hline \multicolumn{2}{|c|}{ PPA 2016-2019 } \\
\hline \multirow{2}{*}{ COMPROMISSO POLÍTICO } & $\begin{array}{l}\text { Ampliar o acesso à educação superior de qualidade, na graduação e na pós- } \\
\text { graduação, contemplando as especificidades da diversidade e da inclusão } \\
\text { e a aprendizagem ao longo da vida, fortalecendo a ciência, a tecnologia e a } \\
\text { inovação, apoiando atividades de ensino, pesquisa e extensão, bem como } \\
\text { aperfeiçoando as atividades de avaliação, supervisão e regulação. } \\
\text { Aprimorar os processos de gestão, monitoramento e avaliação dos sistemas } \\
\text { de ensino, considerando as especificidades da diversidade e inclusão, em } \\
\text { cooperação com os entes federados, estimulando a participação social. }\end{array}$ \\
\hline PRIORIDADES & $\begin{array}{l}\text { Expansão de vagas na educação superior. } \\
\text { Democratização do acesso à educação superior. } \\
\text { Viabilização de estudos nas instituições privadas por financiamento público. } \\
\text { Internacionalização com foco na tecnologia e na qualidade. } \\
\text { Inserção no mercado de trabalho. }\end{array}$ \\
\hline PROCEDIMENTOS & $\begin{array}{l}\text { Ampliação do acesso à educação superior de qualidade. } \\
\text { PROUNI } \\
\text { FIES } \\
\text { SISU }\end{array}$ \\
\hline
\end{tabular}

Fonte: Brasil (2015).

O Plano Plurianual referente a esse período apresenta uma dimensão estratégica concentrando sua programação orçamentária em apenas um programa de governo, denominado Educação de Qualidade para Todos, para o qual foram destinados, para os quatro exercícios financeiros a que ele corresponde, o valor de $\mathrm{R} \$$ 201.203.112.000 (duzentos e um bilhões, duzentos e três milhões e cento e doze mil reais).

Esse valor não se encontra detalhado por ações orçamentárias, a exemplo dos PPAs anteriores, sendo enumerados os objetivos que deverão ser atendidos a partir da utilização dessa dotação orçamentária total, o que será usado nessa seção para promover a relação entre as categorias compromisso político, prioridades e procedimentos, constantes da Mensagem Presidencial, e a programação orçamentária do PPA.

Para a obtenção dessas informações foi lido o Anexo I do PPA 2016-2019, verificando-se todos os seus objetivos, dos quais foram encontradas 46 iniciativas que contêm a educação superior.

A ampliação do acesso à educação superior é um dos itens do compromisso político relativo ao PPA, que compreendeu a elaboração de 29 iniciativas para o período, que também se 
relacionam às prioridades Expansão de vagas na educação superior e Democratização do Acesso à Educação Superior, além da ação de Ampliação do acesso à educação superior de qualidade.

0 aprimoramento dos processos de gestão, monitoramento e avaliação dos sistemas de ensino é outro item do compromisso político que conta com duas iniciativas neste PPA: o Fortalecimento do Sistema Nacional de Avaliação da Educação Superior (SINAES) e o Aperfeiçoamento dos Instrumentos do Sistema Nacional de Pós-Graduação (SNPG). 0 processo de avaliação é uma das preocupações do Governo como forma de mensurar a qualidade da educação.

A viabilização de estudos nas instituições privadas por financiamento público é uma prioridade, constante da Mensagem Presidencial, e se relaciona às ações PROUNI e FIES, para os quais não constam iniciativas específicas.

A internacionalização com foco na tecnologia e na qualidade é outra prioridade para a qual foram identificadas quatro ações na programação do orçamento. A internacionalização promove a troca de experiências entre os países, especialmente no que se refere à tecnologia e inovação, e em relação à educação superior, a internacionalização "vem se constituindo em um dos principais motes da universidade na contemporaneidade" e, comumente, as discussões acerca da internacionalização relacionam-se "à qualidade, à excelência, à inovação, ao conhecimento e a outros diferentes temas, destacando-se, na grande parte das vezes, a contribuição positiva" (MOROSINI; NASCIMENTO, 2017, p. 2) gerada por esse tipo de experiência..

Para a inserção no mercado de trabalho, averiguou-se a existência de três ações na MP. O SISU se refere à última ação relativa à educação superior na Mensagem Presidencial e compreende uma iniciativa específica no PPA 2016-2019 denominada Consolidação do Sistema de Seleção Unificada (SISU) como processo seletivo para acesso a vagas em cursos de gra- duação de instituições públicas e gratuitas de educação superior, com adesão de $100 \%$ das instituições federais vinculadas ao Ministério da Educação. O SISU também contribui para o acesso à educação superior, tendo como base o desempenho do aluno e como objetivos a redução dos gastos com a realização de exames de seleção descentralizados; a diminuição das ineficiências observadas na ocupação das vagas (acúmulo de vagas ociosas); a democratização do acesso à educação superior; e a ampliação da mobilidade geográfica estudantil (ARIOVALDO; NOGUEIRA, 2017).

0 restante do orçamento constante da programação do PPA é referente aos seguintes temas:

Expansão de vagas na educação superior - 2 iniciativas;

Inclusão social - 1 iniciativa;

Manutenção da educação superior - 5 iniciativas.

A dimensão estratégica utilizada em 20162019 não permitiu a apuração dos valores individualizados de cada iniciativa, o que não impossibilitou a verificação da relação entre o conteúdo da Mensagem Presidencial (BRASIL, 2015a) e a programação orçamentária do PPA.

O PPA 2016-2019, segundo plano do governo Dilma, traz uma dimensão que considera o planejamento estratégico do governo, o que define quais serão suas iniciativas, mas não determina seus valores específicos, o que garante uma gestão mais flexível dos recursos orçamentários e financeiros para o governo, mas que não permite a relação direta entre o que foi programado e o que foi colocado na Mensagem Presidencial e impede o estabelecimento de um percentual de atendimento na programação.

Essa nova abordagem é pautada no planejamento estratégico de governo, que utiliza o Plano Plurianual como ferramenta para definição da visão de futuro do governo, bem como o estrutura em dimensão estratégica, tática e operacional, atribuindo os valores orçados so- 
mente ao programa, que representa a reunião de ações com um mesmo propósito e possibilita dispor das dotações orçamentárias para atendimento dos objetivos do programa, mas em conformidade com as demandas de cada ação.

Na metodologia anterior de construção do PPA, os valores para as ações já eram predefinidos, o que dificultava a transferência de valores entre ações. Essa nova forma de compor o PPA trouxe uma flexibilidade, quer no período em que será realizada a ação, quer na distribuição de valores, o que, por outro lado, desvinculou as realizações que antes tinham uma programação mais rígida.

\section{Considerações finais}

O PPA é composto pelo texto da Lei que o aprova, a Mensagem Presidencial que faz sua abertura e configura o que cada governo pretende realizar, além dos anexos que contêm a organização do orçamento público por programas de governo e ações.

0 período de governo analisado, de 2004 a 2019, coincide com o período em que o Partido dos Trabalhadores está no poder; percebeu-se que a destinação de recursos para a Educação Superior brasileira é, em termos de valores investidos, maior do que em governos anteriores, ao mesmo tempo em que demonstra uma diversificação de ações orçamentárias. Tem-se, assim, um maior número de ações orçamentárias nesse período, justificadas pela especificação que visa atender as propostas governamentais no que se refere à regionalização do Plano Plurianual, conforme percebeu-se na expansão da educação superior a municípios, e à facilitação do acesso à educação superior, identificada por intermédio do investimento no financiamento estudantil.

A partir do volume de recursos relativos às categorias analisadas, o primeiro governo do Presidente Lula teve como foco a promoção de uma educação de qualidade, que também considerou o acesso à educação, porém, ainda que o volume de recursos investidos em edu- cação superior no período tenha sido maior em $35,7 \%$, pois passou de $\mathrm{R} \$ 24.838 .282 .404,00$ no governo Fernando Henrique Cardoso para $\mathrm{R}$ \$33.703.490.649,00 nesse período, a relação entre o que foi dito na Mensagem Presidencial e o que foi orçado é de $20,67 \%$.

No seu segundo mandato, atentando para o aspecto financeiro, Lula incrementou o orçamento para a educação superior em 142,8\% e seu foco foi a democratização do acesso à Educação Superior com investimentos no acesso por intermédio da Instituição de Ensino Superior Privada, fomentando o PROUNI, ficando em segundo plano a recuperação das universidades públicas. 0 montante orçamentário destinado ao acesso à educação superior foi de $\mathrm{R} \$$ 6.420.504.778,00 (seis bilhões, quatrocentos e vinte milhões, quinhentos e quatro mil e setecentos e setenta e oito reais), que representa 19,05\% do total investido em educação superior nesse PPA. Desse total, $\mathrm{R} \$$ 5.162.333.461,00 (cinco bilhões, cento e sessenta e dois milhões, trezentos e trinta e três mil e quatrocentos e sessenta e um reais) são referentes ao financiamento estudantil, enquanto R\$ 1.258.171.317,00 (um bilhão, duzentos e cinquenta e oito milhões, centro e setenta e um mil e trezentos e dezessete reais) têm relação com a Reestruturação e Expansão das Universidades Federais.

Dilma continua, no seu primeiro governo, expandindo as matrículas na educação superior e incrementando a concessão de financiamento estudantil, o que é comprovado em razão do investimento realizado, mas começa a desenvolver ações na educação superior brasileira para a formação de mão de obra, com foco no mercado de trabalho. Além disso, programou ações no Plano Plurianual para a interiorização da educação superior e para os instrumentos de avaliação dessa educação, o que ressalta a preocupação com a qualidade.

0 último período de governo da Presidente Dilma revelou um maior investimento em educação superior, comparativamente com os demais períodos analisados, quando tam- 
bém foi apurado que todo o conteúdo posto na Mensagem Presidencial guarda iniciativas para sua execução, representadas nos $\mathrm{R} \$$ 201.203.112.000 (duzentos e um bilhões, duzentos e três milhões e cento e doze mil reais) reservados para o seu atendimento.

No entanto, essa nova dimensão estratégica, que não define valores específicos para as iniciativas listadas, não viabiliza estabelecer o que é prioritário para a presidente no que se refere à Educação Superior, levando-se em conta o aspecto financeiro.

A investigação do conteúdo da Mensagem Presidencial, confrontado com a programação orçamentária, propiciou o exame do que foi consolidado em termos orçamentários. Foi possível estabelecer uma relação entre o que foi dito pelo governante e a alocação de recursos nas ações de governo.

Percebeu-se que o plano político estabelecido pelo Governo do Partido dos Trabalhadores é edificado a partir não só da menção de seu conteúdo pelo compromisso político, prioridades e procedimentos em cada Plano Plurianual, mas, especialmente, na respectiva programação orçamentária demonstrada nas ações orçamentárias.

0 acesso à educação superior, constante desse plano do PT, é conteúdo de todos os Planos Plurianuais, representando 19,05\% do total programado para a educação superior no PPA 2004-2007, 11,05\% no PPA 2008-2011 (1,66\% em Democratização do Acesso ao Ensino Superior e 9,39\% no Prouni), 5,90\% no PPA 2012-2015 (5,26\% em Expansão de matrículas na educação superior e 0,64\% em Acesso ao ensino superior onde a oferta é reduzida) e compreendido em Expansão de vagas na educação superior, Democratização do acesso à Educação Superior e Ampliação do acesso à educação superior de qualidade no PPA 2016-2019, em que não são atribuídos valores detalhados da programação orçamentária para as ações.

Considerado ainda o plano político do PT, o financiamento estudantil é evidenciado nos planos plurianuais da presidente Dilma
Roussef em 4,95\% do total programado para o conteúdo da Mensagem Presidencial em 2012-2015 e no Prouni em 2016-2019, para os quais não são atribuídos recursos específicos, em razão da dimensão estratégica do PPA, já explicada.

Esses dados confirmam as intenções governamentais para a Educação Superior para cada Plano Plurianual, esclarecendo o que de fato foi cumprido pelo Governo relativamente à Educação Superior no Brasil, no que se refere à destinação de recursos. Ressalta-se que apenas o que foi programado foi examinado, não sendo conhecida a efetivação dessas ações via execução orçamentária e financeira.

\section{REFERÊNCIAS}

AMARAL, Nelson Cardoso. A educação superior brasileira: papel, funções e financiamento. In: ESTRELA, Carlos (Org.). Metodologia científica: ciência, ensino e pesquisa. 3. ed. Porto Alegre: Artes Médicas, 2018. p. 7-25.

AMARAL, Nelson Cardoso; CHAVES, Vera Lúcia Jacob. Política de financiamento da educação superior - análise dos Planos Nacionais de Educação pós-constituição/1988. Revista Eletrônica de Educação, São Carlos, SP, v. 8, n. 1, p. 43-55, 2014.

AMORIM, Ivan Trizi. A institucionalização do plano plurianual (PPA): um estudo no governo federal brasileiro nos períodos 2002-2003 e 2004-2007. 2016. 155 f. Dissertação (Mestrado em Ciências) - Programa de Pós-Graduação em Administração do Departamento de Administração da Faculdade de Economia, Administração e Contabilidade, Universidade de São Paulo (USP), São Paulo, 2016.

ARIOVALDO, Thainara Cristina de Castro; NOGUEIRA, Cláudio Marques Martins. Nova forma de acesso ao ensino superior público: um estado do conhecimento sobre o sistema de seleção unificada - SISU. Revista Internacional de Educação Superior, Campinas, SP, v. 4, n. 1, p. 152-174, 2017.

BAUER, Martin W.; GASKELL, George. Pesquisa qualitativa com texto, imagem e som: um manual prático. Petrópolis, RJ: Vozes, 2002.

BRASIL. Presidência da República. Casa Civil. Constituição da República Federativa do Brasil de 
1988. Brasília, DF, 1998. Disponível em: http:// www.planalto.gov.br/ccivil_03/constituicao/ constituicao.htm. Acesso em: out. 2017.

BRASIL. Ministério do Planejamento, Orçamento e Gestão. Secretaria de Planejamento e Investimentos Estratégicos. Plano Plurianual 2004-2007: mensagem presidencial. Brasília, DF, 2003a.

BRASIL. Ministério do Planejamento, Desenvolvimento e Gestão. Plano Plurianual 2004-2007. Brasília, DF, 2003b. Disponível em: http://www.planejamento.gov.br/assuntos / planeja/plano-plurianual. Acesso em: out. 2017.

BRASIL. Presidência da República. Casa Civil. Lei n ${ }^{\circ}$ 10.933, de 11 de agosto de 2004. Dispõe sobre o Plano Plurianual para o período 2004/2007. Brasília, DF, 2004. Disponível em: http://www. planalto.gov.br/ccivil_03/_Ato2004-2006/2004/ Lei/L10.933.htm. Acesso em: out. 2017.

BRASIL. Ministério do Planejamento, Orçamento e Gestão. Secretaria de Planejamento e Investimentos Estratégicos. Plano Plurianual 2008-2011: mensagem presidencial. Brasília, DF, 2007a.

BRASIL. Ministério do Planejamento, Desenvolvimento e Gestão. Plano Plurianual 2008-2011. Brasília, DF, 2007b. Disponível em: http://www.planejamento.gov.br/assuntos/ planeja/plano-plurianual. Acesso em: out. 2017.

BRASIL. Presidência da República. Casa Civil. Lei $\mathrm{n}^{\circ} \mathbf{1 1 . 6 5 3}$, de $\mathbf{7}$ de abril de 2008. Dispõe sobre o Plano Plurianual para o período 2008/2011. Brasília, DF, 2008. Disponível em: http://www. planalto.gov.br/ccivil_03/_Ato2007-2010/2008/ Lei/L11653.htm. Acesso em: out. 2017.

BRASIL. Ministério do Planejamento, Orçamento e Gestão. Secretaria de Planejamento e Investimentos Estratégicos. Plano Plurianual 2012-2015: mensagem presidencial. Brasília, DF, 2011a.

BRASIL. Ministério do Planejamento, Desenvolvimento e Gestão. Plano Plurianual 2012-2015. Brasília, DF, 2011b. Disponível em: http://www.planejamento.gov.br/assuntos/ planeja/plano-plurianual. Acesso em: out. 2017.

BRASIL. Presidência da República. Casa Civil. Lei n 12.593, de 18 de janeiro de 2012. Dispõe sobre o Plano Plurianual para o período 2012/2015. Brasília, DF, 2012. Disponível em: http://www. planalto.gov.br/ccivil_03/_ato2011-2014/2012/ Lei/L12593.htm. Acesso em: out. 2017.

BRASIL. Ministério da Educação. Planejando a pró- xima década: conhecendo as 20 metas do plano nacional de educação. Brasília, DF: MEC, Secretaria de Articulação com os Sistemas de Ensino (MEC/ Sase), 2014. Disponível em: http://pne.mec.gov. br/images/pdf/pne_conhecendo_20_metas.pdf. Acesso em: 20 ago. 2018.

BRASIL. Ministério do Planejamento, Orçamento e Gestão. Secretaria de Planejamento e Investimentos Estratégicos. Plano Plurianual 2016-2019: mensagem presidencial. Brasília, DF, 2015.

BRASIL. Presidência da República. Casa Civil. Lei ${ }^{\circ}$ 13.249, de 13 de janeiro de 2016. Dispõe sobre o Plano Plurianual para o período 2016/2019. Brasília, DF, 2016. Disponível em: http://www. planalto.gov.br/ccivil_03/_ato2015-2018/2016/ Lei/L13249.htm. Acesso em: out. 2017.

CASTRO, Jorge Abrahão. Financiamento da educação no Brasil. Em Aberto, Brasília, DF, v. 18, 2001.

CERUTTI, Elizabete. et al. Avaliação da educação superior brasileira: diálogos mediados pelo white paper. Revista Educação por Escrito, Porto Alegre, v. 2, n. 1, p. 55-74, 2011.

FERREIRA, Sinésio Pires; SANTOS, Tarsila Peres; SOUSA, Cassiana Montesião de. Planejamento público e avaliação de políticas. In: BASSOTTI, Ivani Maria; SANTOS, Thiago Souza (org.). Tópicos essenciais sobre gestão pública. São Paulo: Unidade Central de Recursos Humanos da Secretaria de Planejamento e Gestão, 2016. p. 69-116.

JESUS, Jorge Alberto Santana de. A política de expansão e interiorização do ensino superior através da Universidade Aberta do Brasil: a experiência da UNIVASF no vale do submédio São Francisco. 2016. 105 f. Dissertação (Mestrado Profissional em Gestão de Políticas Públicas e Segurança Social) - Programa de Pós-Graduação em Gestão de Políticas Públicas e Segurança Social, Universidade Federal do Recôncavo da Bahia (UFRB), Cruz das Almas, BA, 2016.

LIMA, Marcelo; PACHECO, Zilka Sulamita Teixeira de Aguilar. As políticas públicas e o direito à educação: Programa Nacional de Acesso ao Ensino Técnico e Emprego versus Plano Nacional de Educação. Revista Educação e Sociedade, Campinas, SP, v. 38, n. 139, p. 489-504, 2017.

MOROSINI, Marília Costa; NASCIMENTO, Lorena Machado. Internacionalização da educação superior no Brasil: a produção recente em teses e dissertações. Educação em Revista, Belo Horizonte, n. 33, 2017. Disponível em: http:// 
www.scielo.br/pdf/edur/v33/1982-6621-edur33-e155071.pdf. Acesso em: abr. 2017.

OLIVEIRA, Fábio Corrêa Souza de. Por uma teoria dos princípios: o princípio constitucional da razoabilidade. Rio de Janeiro: Lumen Juris, 2003.

PARTIDO DOS TRABALHADORES (PT). Programa de Governo 2003-2006. São Paulo, 2002. Disponível em: http://www.pt.org.br. Acesso em: abr. 2019.

PARTIDO DOS TRABALHADORES (PT). Programa de Governo 2007-2010. São Paulo, 2006. Disponível em: http://www.pt.org.br. Acesso em: abr. 2019.

PARTIDO DOS TRABALHADORES (PT). Programa de Governo 2011-2014. São Paulo, 2010. Disponível em: http://www.pt.org.br. Acesso em: abr. 2019.

PARTIDO DOS TRABALHADORES (PT). Programa de Governo 2015-2018. São Paulo, 2014. Disponível em: http://www.pt.org.br. Acesso em: abr. 2019.
PINTO, José Marcelino de Rezende; ADRIÃO, Theresa. Noções gerais sobre o financiamento da educação no Brasil. Revista Eccos, São Paulo, v. 8, n. 1, p. 23-46, jan./jun. 2006.

SANTOS, Eugênio; VENTURA, Otávio; NETO, Rafael. As inovações jurídicas no PPA 20122015. In: CARDOSO JÚNIOR, José Celso; SANTOS, Eugênio A. Vilela dos (org.). PPA 2012-2015: experimentalismo institucional e resistência burocrática. Brasília, DF: IPEA, 2015. p. 69-91.

SCHWARTZMAN, Jacques. 0 financiamento do ensino superior no Brasil na década de 90. In: SOARES, Maria Susana Arrosa (org.). A educação superior no Brasil. Porto Alegre: UNESCO/IESALC, 2002. p. 194-222.

SILVA, Valmir Leôncio da. A nova contabilidade aplicada ao setor público: uma abordagem prática. São Paulo: Atlas, 2012.

Recebido em: 13/05/2019 Aprovado em: 30/07/2019 